\title{
Influence of Edaphic Attributes on the Distribution of Tree Species in a Riparian Forest in Southern Brazil
}

\author{
Mônica Brucker Kelling ${ }^{1}$ (D), Maristela Machado Araujo ${ }^{1}$ (D), \\ Daniele Guarienti Rorato ${ }^{1}$ (D) \\ ${ }^{1}$ Universidade Federal de Santa Maria (UFSM), Santa Maria, RS, Brasil
}

\begin{abstract}
This study aims at identifying the formation of clusters and to evaluate the influence of chemical attributes in the soil on the groups and species in a riparian forest fragment in Campos de Cima da Serra, Rio Grande do Sul (RS). Thirteen plots $(10 \times 20 \mathrm{~m})$ were demarcated to carry out the study. Forest inventory data were employed in a multivariate analysis using the Twinspan method and the correlation between vegetation data and chemical characterization of the soil was carried out by Canonical Correspondence Analysis (CCA). Thirty-one species were sampled (DBH $\geq 30 \mathrm{~cm}$ ) and two floristic groups were identified. The results indicated a structural difference between the two environments, likely due to the steeper slope and less influence of groundwater. Variables such as sulfur, calcium and organic matter were explanatory of the vegetation grouping known as riparian forest of hillside and aluminum, aluminum saturation and copper of riparian forest with flat topography.
\end{abstract}

Keywords: conservation, cluster analysis, canonical correspondence analysis, Mixed Ombrophilous Forest. 


\section{INTRODUCTION AND OBJECTIVES}

The vegetation found along watercourses is generally referred to as riparian (Brasil, 2012), however, when this vegetation is not characterized as a continuous forest, it is often referred to as a gallery forest (Rodrigues, 2009). Regardless of the denomination, riparian forests play an important biological filter role by retaining substances or by filtering water runoff (Kageyama \& Gandara, 2009), as well as forming ecological corridors that are fundamental for preserving the diversity of flora and fauna (Brancalion et al., 2010). Due to its importance, the development of researches related to the phytosociological parameters of the vegetation present in riparian forests is an important subsidy for planning conservation actions and enrichment of these areas.

In this regard, the use of multivariate techniques such as cluster analysis is an important tool to characterize vegetation in forest fragments, since it aims to cluster elements in homogeneous groups (Felfili \& Rezende, 2003). Among the implemented techniques, the Twinspan (Two-Way Indicator Species Analysis) grouping analysis (Gauch, 1982) has been used by Araujo et al. (2010), thus allowing the detection of distinct vegetation clusters in forest remnants, which were defined according to environmental characteristics and specific species.

Moreover, as important as characterizing floristic and vegetation structure, as well as evidencing groupings of species in natural ecosystems, is the correlation of this information with environmental characteristics. This is possible through sorting methods such as the Canonical Correspondence Analysis (CCA), Principal Component Analysis (PCA) and Detrended Correspondence Analysis (DCA), which were used by Rodrigues et al. (2007). According to these techniques, these authors determined preferential habitats for species occurrence which were correlated with the type and characteristics of soils, topography and drainage.

Similarly, Avila et al. (2011) also used cluster analysis and CCA, respectively, to identify the presence of floristic clusters in natural regeneration mechanisms and the influence of environmental factors on the distribution of species and plots in the seedling bank in a Mixed Ombrophilous Forest fragment in southern Brazil. In this forest typology, the authors concluded that the formed clusters indicate differences in the regenerative processes of the forest. Understanding this information makes it possible to plan conservation and management strategies that are appropriate to each species and environment, and according to Rorato et al. (2015), allows one inferring about the biological conservation of these ecosystems, providing an indication of potential species to be used in programs and strategies for recovery and enrichment of degraded areas.

Thus, the objective of the present study was to identify and characterize groupings of species in the arboreal component and correlate them with soil variables in a riparian forest in Campos de Cima da Serra in RS, Brazil.

\section{MATERIALS AND METHODS}

The study was carried out in an area of riparian forest in a Mixed Ombrophilous Montana Forest fragment (IBGE, 2012) in the municipality of São Francisco de Paula, RS $\left(29^{\circ} 26^{\prime} 52^{\prime \prime} S\right.$ latitude and $50^{\circ} 35^{\prime} 02^{\prime \prime} \mathrm{W}$ longitude), with average altitudes of $907 \mathrm{~m}$. According to the Köppen climate classification, the climate in the region is $\mathrm{Cfb}$ (subtropical), constituting the coldest region of the state and with the greatest precipitation (Moreno, 1961).

The region is known as Campos de Cima da Serra, in which the fields form mosaics with the Mixed Ombrophilous Forest (Pillar et al., 2009) and the Campos Sulinos biome (IBGE, 2004). According to Streck et al. (2008), the predominant soils in the region are classified in the first categorical level as Cambisols and Neosols.

Systematic sampling was used for the vegetation survey with random selection of the first sample unit (plot), and all other units were then systematically distributed from there (Péllico Neto \& Brena, 1997). Thus, eight strips perpendicular to the water course were demarcated, parallel to one another at distances of $100 \mathrm{~m}$. The strips were drawn in the perpendicular direction to the drainage line in order to obtain a vegetation gradient from the fragment edge to the riverbed (Figure 1).

A total of 13 plots of $10 \times 20 \mathrm{~m}$ were demarcated throughout the eight strips in the fragment with a total area of 12.2 ha. Botanical identification and 


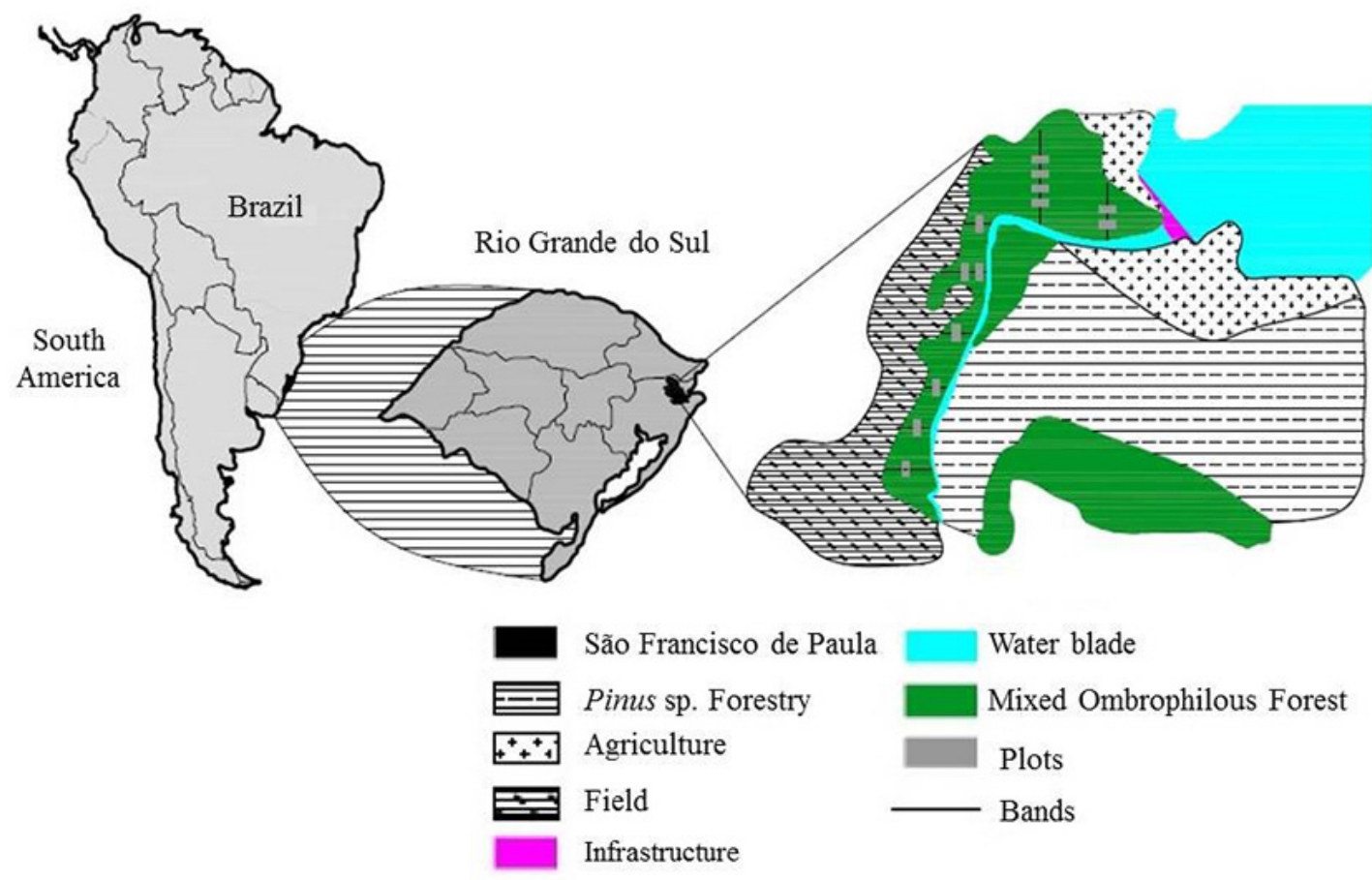

Figure 1. Location of the study area, highlighting the distribution of the strips and plots sampled in a Mixed Ombrophilous Forest fragment, São Francisco de Paula, RS, Brazil.

measurement of the individuals of the shrub-arboreal component of the diameter at breast height (DBH), according to class sizes, was carried out in each plot. All individuals with $\mathrm{DBH} \geq 30 \mathrm{~cm}$ (Class I) were evaluated in the total area of each plot $(10 \times 20 \mathrm{~m})$, while all individuals with $15 \leq \mathrm{DBH}<30 \mathrm{~cm}$ (Class II) were evaluated in the $10 \times 10 \mathrm{~m}$ subplots. The species were classified into botanical families according to the Angiosperm Phylogeny Group (APG IV) (Chase, 2016) and the scientific name updating was determined according to the List of Species of the Brazilian Flora (JBRJ, 2014).

In addition to the vegetation survey, three simple soil samples in the 0-20 cm layer were collected from eight of the 13 plots studied to form the composite sample. These samples were submitted to chemical analysis at the Universidade Federal de Santa Maria (UFSM) Soil Analysis Laboratory according to the methodology proposed by Tedesco et al. (1995) for determining the $\mathrm{pH}$ in water, $\mathrm{V} \%$ (base saturation), $\mathrm{m} \%$ (saturation by aluminum), $\mathrm{H}+\mathrm{Al}$, effective cation exchange capacity (CEC), pH7 CEC, and content of organic matter $(\mathrm{OM})$, aluminum (Al), calcium $(\mathrm{Ca})$, magnesium $(\mathrm{Mg})$, potassium $(\mathrm{K})$, sulfur $(\mathrm{S})$, phosphorus $(\mathrm{P})$, copper $(\mathrm{Cu})$, boron $(\mathrm{B})$ and zinc $(\mathrm{Zn})$.

The cluster analysis only considered data from individuals of the arboreal stratum (Class I), while Class II was used to support possible biological and structural differences in each grouping based on the evaluated class sizes. Thus, tree vegetation data (individuals with $\mathrm{DBH} \geq 30 \mathrm{~cm}$ ) gave rise to a matrix consisting of 13 plots (lines) and 14 species (columns). Rare species (considered as those with less than three individuals) were removed from the cluster analysis. Rare or low-density species have little or no influence on the results and can be removed from the analysis (Gauch, 1982).

This matrix was used in a multivariate analysis according to the Twinspan method (Gauch, 1982) using the PC-ORD ${ }^{\mathrm{TM}}$ program for Windows version 5.10 (McCune \& Mefford, 1997).

For characterization of the pseudospecies, the cut levels were determined based on the densities observed 
for the species in each plot with pseudospecies 1 (up to one individual), pseudospecies 2 (two to four), pseudospecies 3 (five to six), pseudospecies 4 (seven to nine) and pseudospecies 5 (10 or more individuals).

According to the formed groups, each one was then analyzed by parameters such as density, dominance, absolute frequency and value of importance regarding the species (Felfili \& Rezende, 2003), seeking to distinguish differences in the forest structure, which in addition to density also allowed to infer about each group.

The correlation between vegetation data and soil chemical variables through the Canonical Correspondence Analysis (CCA) was carried out using the PC-ORD ${ }^{\mathrm{TM}}$ program for Windows version 5.10 (McCune \& Mefford, 1997). The analysis was based on the formation of two matrices: one referring to the density of the individuals of each tree species in the eight plots from which soil samples were collected; and another one containing the chemical characteristics of the soil, in addition to the group as a categorical variable. However, the analysis is only possible when the number of environmental variables is smaller than the number of plots with vegetation data; a condition imposed by the software at the time of inserting the matrices in the program. Thus, a preliminary analysis was carried out to remove weakly correlated variables (correlation value less than 0.4).

As a result, CCA was processed using the main matrix of species density (Class I), composed by eight plots (lines) and 11 species (columns), and a secondary matrix with eight plots (lines) and seven environmental variables (columns). It was then possible to evaluate soil chemical variables that had the greatest influence on the groups according to the CCA results.

\section{RESULTS AND DISCUSSION}

For the arboreal vegetation (Class I, DBH $\geq 30 \mathrm{~cm}$ ) of the studied forest fragment, 31 species belonging to 27 genera and 19 botanical families were sampled, while for the smaller class size (Class II, $15 \leq \mathrm{DBH}<30 \mathrm{~cm}$ ), the richness was represented by 19 species, 19 genera and 12 botanical families (Table 1). Ribeiro et al. (2007) verified the occurrence of 130 species with $\mathrm{DBH} \geq 30 \mathrm{~cm}$ belonging to 79 genera and 45 botanical families in an arboreal community characterization of the Mixed Ombrophilous Forest in the National Forest (Flona) of São Francisco de Paula, RS, Brazil. These results differ from those found herein, probably due to the studied area belonging to a Flona and representing a typical Mixed Ombrophilous Forest, while the forest fragment in the present study is represented by a riparian forest remnant.

Two floristic groups (eigenvalue: 0.3133) were observed in the cluster analysis for Class I: Group 1 (G1) and Group 2 (G2) (Figure 2). According to the characteristic of the observed vegetation, the studied forest fragment shows a great number of species of riparian forests. However, G1 differed from $\mathrm{G} 2$ because it occurred on flat relief, thus being referred to as riparian forest with flat topography, using Eugenia uruguayensis as an indicator. The area in G2 has a more pronounced topography, which can be characterized as a hillside riparian forest, in which the indicator species of this environment was Myrcianthes gigantea. Both indicator species are typical of riparian forests, as evidenced by Rorato et al. (2015) for Eugenia uruguayensis and by Backes \& Irgang (2009) for Myrcianthes gigantea.

The species Casearia decandra, Eugenia uruguayensis, Myrciaria delicatula, Myrsine coriacea, Roupala brasiliensis and Styrax leprosus are the preferential species of the riparian forest with flat topography (G1) (six plots) as represented by pseudospecies 1 , which indicates a low density of individuals in the plots. In addition to these, we can highlight Eugenia uruguayensis and Ocotea pulchella, belonging to pseudospecies 2, which presented between two and four individuals; and Eugenia uruguayensis and Podocarpus lambertii, both of pseudospecies 3 with five to six individuals.

For the hillside riparian forest (G2) formed by seven plots, the species Myrcianthes gigantea was indicative of the group and also the preferred pseudospecies 1 and 2, while Gymnanthes klotzschiana was preferred as pseudospecies 2, 3, 4 and 5, considering that more than 10 individuals of this species were observed in both plots.

In the G1 structure, represented by the riparian forest present in areas with flat topography, approximately 1,008 individuals.ha ${ }^{-1}$ were found for Class I (DBH $\geq 30 \mathrm{~cm}$ ), belonging to 24 species, 23 genera and 14 botanical families (Table 2). 
The species present in the riparian forest with flat topography (G1) that showed the highest values of importance were: Podocarpus lambertii (21.6\%), Eugenia uruguayensis (13.5\%), Araucaria angustifolia (9.3\%) and Ilex brevicuspis (7.6\%), representing 52\% of the group's horizontal structure (Table 2). Of these,
Podocarpus lambertii and Ilex brevicuspis were not represented in Class II $(15 \leq \mathrm{DBH}<30 \mathrm{~cm})$, while Eugenia uruguayensis and Araucaria angustifolia were found in both studied classes, thus suggesting the greater possibility of preserving these species in the environment. In this group, it should also be

Table 1. Families and species observed in Class I $(\mathrm{DBH} \geq 30 \mathrm{~cm})$ and Class II $(15 \leq \mathrm{DBH}<30 \mathrm{~cm})$ in a Mixed Ombrophilous Forest fragment. São Francisco de Paula, RS, Brazil.

\begin{tabular}{|c|c|c|c|}
\hline Family & Species & $\begin{array}{l}\text { Popular name } \\
\text { in Brazil }\end{array}$ & Class \\
\hline \multirow[t]{2}{*}{ Anacardiaceae } & Lithraea brasiliensis Marchand & Aroeira-brava & I and II \\
\hline & Schinus lentiscifolia Marchand & Aroeira-cinzenta & I and II \\
\hline \multirow{2}{*}{ Aquifoliaceae } & Ilex brevicuspis Reissek & Caúna & I and II \\
\hline & Ilex dumosa Reissek & Caúna & I \\
\hline Araucariaceae & Araucaria angustifolia (Bertol.) Kuntze & Araucária & I and II \\
\hline Asteraceae & Gochnatia polymorpha (Less.) Cabr. & Cambará & I \\
\hline Celastraceae & Maytenus aquifolia Mart. & Cancorosa & I \\
\hline Cunoniaceae & Lamanonia ternata Vell. & Guaraperê & I \\
\hline Dicksoniaceae & Dicksonia sellowiana Hook. & Xaxim & I \\
\hline \multirow[t]{2}{*}{ Euphorbiaceae } & Sebastiania brasiliensis Marchand & Leiteiro & I and II \\
\hline & Gymnanthes klotzschiana Müll.Arg. & Branquilho & I and II \\
\hline \multirow[t]{4}{*}{ Lauraceae } & Cinnamomum amoenum (Nees \& Mart.) Kosterm. & Canela & I \\
\hline & Ocotea corymbosa (Meisn.) Mez & Canela & I \\
\hline & Ocotea porosa (Nees \& Mart.) Barroso & Imbúia & I \\
\hline & Ocotea pulchella (Nees \& Mart.) Mez & Canela-lageana & I and II \\
\hline Melastomataceae & Miconia cinerascens Miq. & Pixirica & II \\
\hline \multirow[t]{7}{*}{ Myrtaceae } & Acca sellowiana (O.Berg) Burret & Goiaba-da-serra & II \\
\hline & Blepharocalyx salicifolius (Kunth) O.Berg & Murta & I \\
\hline & Calyptranthes concinna DC. & Guamirim-ferro & I and II \\
\hline & Eugenia uruguayensis Cambess. & Guamirim & I and II \\
\hline & Myrceugenia cucullata D. Legrand & Guamirim & I and II \\
\hline & Myrcianthes gigantea (D. Legrand) D. Legrand & Araçá-do-mato & I and II \\
\hline & Myrciaria delicatula (DC.) O.Berg & Camboim & I and II \\
\hline Podocarpaceae & Podocarpus lambertii Klotzsch ex Endl. & Pinheiro-bravo & I and II \\
\hline Primulaceae & $\begin{array}{l}\text { Myrsine coriacea (Sw.) R.Br. } \\
\text { ex Roem. \& Schult. }\end{array}$ & Capororoca & I \\
\hline Proteaceae & Roupala brasiliensis Klotzsch & Carvalho-brasileiro & I and II \\
\hline Quillajaceae & Quillaja brasiliensis (A.St.-Hil. \& Tul.) Mart. & Pau-sabão & I and II \\
\hline Rosaceae & Prunus myrtifolia (L.) Urb. & Pessegueiro-do-mato & I \\
\hline \multirow[t]{2}{*}{ Salicaceae } & Casearia decandra Jacq. & Guaçatunga & I and II \\
\hline & Casearia sylvestris Swartz. & Chá-de-bugre & I \\
\hline Sapindaceae & Allophylus edulis (A.St.-Hil. et al.) Hieron. ex Niederl. & Chal-chal & I \\
\hline Styracaceae & Styrax leprosus Hook. \& Arn. & Carne-de-vaca & I \\
\hline Symplocaceae & Symplocos uniflora (Pohl) Benth. & Sete-sangrias & I and II \\
\hline
\end{tabular}




\section{Set of plots}

1 st division eigenvalue: 0.3133

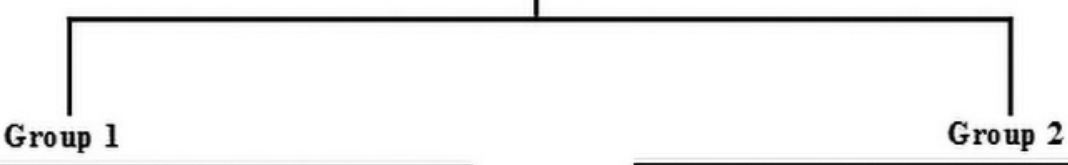

\begin{tabular}{|l|}
\hline Plots: $21,27,28,29,30,31$. \\
\hline $\begin{array}{l}\text { Indicator Species: Eugenta } \\
\text { uruguayensis } 1\end{array}$ \\
\hline Preferential Species: Cas.dec $1(3$, \\
0), Eug.uru $1(7,2)$, Myr.del $1(3,1)$, \\
Myrs.cor $1(3,1)$, Roup.bra $1(3,0)$, \\
Sty.lep $1(2,0)$, Eug.uru $2(7,2)$, \\
Ocot.pul $2(2,0)$, Eug.uru $3(2,0)$, \\
Pod.lam $3(4,1)$.
\end{tabular}

\begin{tabular}{|l|}
\hline Plots: $20,22,23,24,25,26,32$. \\
\hline Indicator Species: Myrcianthes \\
gigantea 1 \\
\hline Preferential Species: Myrc.gig $1(0$, \\
4), Myrc.gig $2(0,2)$, Gym.klo $2(2$, \\
4), Gym.klo $3(0,4)$, Gym.klo $4(0$, \\
3), Gym.klo 5 $(0,2)$. \\
\end{tabular}

Abbreviations: Eug.uru: Eugenia uruguayensis; Cas.dec: Casearia decanaira, Gym.klo: Gymnanthes klotschiana, Myrc.gig: Myrcianthes gigantea, Myrs.cor: Myrsine coriacea, Myr.del: Myrciaria delicatula; Ocot.pul: Ocotea puichella; Pod.lam: Pocarpus lambertii, Roup.bra: Roupala brasiliensis; Sty.lep: Styrax leprosus.

Note: The number after the abbreviation refers to pseudospecies (cut level). The number in parentheses refers to the number of plots where the pseudospecies are contained on both sides of the division.

Figure 2. Classification of sampling units in two floristic groups for Class I $(\mathrm{DBH} \geq 30 \mathrm{~cm})$ in a Mixed Ombrophilous Forest fragment. São Francisco de Paula, RS, Brazil, as follows: Group 1: riparian forest with flat topography; Group 2: hillside riparian forest.

noted that Casearia decandra, Myrciaria delicatula, Myrcengenia cucullata and Roupala brasiliensis were also found represented in both classes, with their propagation being favored in this environment.

For Class I $(\mathrm{DBH} \geq 30 \mathrm{~cm})$ of the hillside forest (G2), it was found the occurrence of 900 individuals. $\mathrm{ha}^{-1}$ belonging to 18 species, 17 genera and 11 botanical families (Table 3). The species that presented the highest value of importance were Araucaria angustifolia (20.6\%), Gymnanthes klotzschiana (19.6\%), Lithraea brasiliensis (14.1\%) and Podocarpus lambertii (9,6\%), representing $63.9 \%$ of the forest structure. Of these species, except for Araucaria angustifolia, all the others are present in both evaluated classes, indicating the possibility of their propagation over time.

The riparian forest with flat topography (G1) had a basal area expressed by absolute total dominance (ADo) of $48.28 \mathrm{~m}^{2} \cdot \mathrm{ha}^{-1}$ (Table 2), while it was ADo $=37.73 \mathrm{~m}^{2} \cdot$ ha $^{-1}$ for the hillside riparian forest (G2) (Table 3). The highest values found for G1 in relation to G2 regarding the number of species and number of individuals indicate a structural difference of these two environments, probably due to the greater slope and less influence of the water table on G2. On the other hand, even though G2 is located on higher ground, it clearly reflects the condition of a riparian forest considering the predominance of Gymnanthes klotzschiana, a typical species of these environments. The soil of the studied forest area was classified by Rorato et al. (2015) as Litholic Neosols. This soil class is characterized by recent pedogenesis and its occurrence on steep slopes (Streck et al., 2008), and it imposes root growth restrictions due to low depth and low nutritional content, thereby experiencing consequent colonization by plant species, as can be evidenced by differences in the phytosociological parameters of Classes I and II in both clusters.

Tables 2 and 3 show that species belonging to Class I with the highest value of importance are common for both groups, indicating the similarity of the floristic composition between these environments. Regarding Class II, we can verify that only 10 of the 24 species present in Class I are represented in this class in G1 (Table 2). 
Table 2. Phytosociological parameters of the species belonging to Group 1, considering Class I and Class II in a Mixed Ombrophilous Forest fragment. São Francisco de Paula, RS, Brazil.

\begin{tabular}{|c|c|c|c|c|c|c|c|c|}
\hline \multirow{2}{*}{ SCIENTIFIC NAME } & \multicolumn{4}{|c|}{ CLASS I } & \multicolumn{4}{|c|}{ CLASS II } \\
\hline & AD & ADo & AF & VI & AD & ADo & AF & VI \\
\hline Podocarpus lambertii & 225 & 15.1796 & 100 & 21.6 & & & & \\
\hline Eugenia uruguayensis & 183.3 & 5.6272 & 100 & 13.5 & 50 & 0.4161 & 33.3 & 14.6 \\
\hline Araucaria angustifolia & 75 & 7.3202 & 50 & 9.3 & 33.3 & 0.1391 & 16.7 & 6.8 \\
\hline Ilex brevicuspis & 83.3 & 4.4565 & 50 & 7.6 & & & & \\
\hline Lithraea brasiliensis & 58.3 & 3.548 & 66.7 & 6.7 & 16.7 & 0.0613 & 16.7 & 4.2 \\
\hline Gymnanthes klotzschiana & 50 & 1.4577 & 66.7 & 5 & & & & \\
\hline Ocotea pulchella & 25 & 3.0763 & 33.3 & 4.1 & & & & \\
\hline Casearia decandra & 33.3 & 0.7983 & 50 & 3.4 & 66.7 & 0.3507 & 50.0 & 16.7 \\
\hline Roupala brasiliensis & 33.3 & 0.7957 & 50 & 3.4 & 16.7 & 0.0454 & 16.7 & 3.9 \\
\hline Ocotea porosa & 25 & 0.9721 & 50 & 3.3 & & & & \\
\hline Myrciaria delicatula & 33.3 & 0.5764 & 50 & 3.3 & 66.7 & 0.2915 & 33.3 & 13.9 \\
\hline Myrsine coriacea & 41.7 & 0.8915 & 33.3 & 3.2 & & & & \\
\hline Myrceugenia cucullata & 33.3 & 0.4373 & 50 & 3.2 & 33.3 & 0.1025 & 33.3 & 8.1 \\
\hline Styrax leprosus & 25 & 0.8268 & 33.3 & 2.6 & & & & \\
\hline Schinus lentiscifolia & 8.3 & 0.6765 & 16.7 & 1.3 & & & & \\
\hline Dicksonia sellowiana & 8.3 & 0.2155 & 16.7 & 1 & & & & \\
\hline Symplocos uniflora & 8.3 & 0.1725 & 16.7 & 1 & 33.3 & 0.1767 & 16.7 & 7.5 \\
\hline Calyptranthes concinna & 8.3 & 0.1434 & 16.7 & 1 & 16.7 & 0.0590 & 16.7 & 4.2 \\
\hline Cinnamomum amoenum & 8.3 & 0.1226 & 16.7 & 0.9 & & & & \\
\hline Lamanonia ternata & 8.3 & 0.117 & 16.7 & 0.9 & & & & \\
\hline Ocotea corymbosa & 8.3 & 0.0998 & 16.7 & 0.9 & & & & \\
\hline Sebastiania brasiliensis & 8.3 & 0.0722 & 16.7 & 0.9 & 33.3 & 0.1460 & 16.7 & 7.0 \\
\hline Casearia sylvestris & 8.3 & 0.0637 & 16.7 & 0.9 & & & & \\
\hline Gochnatia polymorpha & 8.3 & 0.0597 & 16.7 & 0.9 & & & & \\
\hline Miconia cinerascens & & & & & 16.7 & 0.052 & 16.7 & 4.1 \\
\hline Myrcianthes gigantea & & & & & 33.3 & 0.1599 & 33.3 & 9.0 \\
\hline TOTAL & 1008.3 & 48.283 & 950 & 100 & 416.7 & 2.0004 & 300 & 100 \\
\hline
\end{tabular}

AD: absolute density (individuals.ha $\left.{ }^{-1}\right)$; ADo: absolute dominance $\left(\mathrm{m}^{2} . \mathrm{ha}^{-1}\right)$; AF: absolute frequency (\%); VI: value of importance (\%); Class I $(\mathrm{DBH} \geq 30 \mathrm{~cm})$; Class II $(15 \leq \mathrm{DBH}<30 \mathrm{~cm})$.

We can probably consider that the greater shading within the vegetation grouping characterized as hillside riparian forest (G2), due to its slope in relation to facing south and associated with the canopy cover, has created a better condition for the natural regeneration of Podocarpus lambertii in this environment than in that of riparian forest with flat topography (G1) (Table 3). On the other hand, Araucaria angustifolia had a higher natural regeneration in G1 due to the more heliophilous character in that region (Table 2).

The CCA results indicated the influence of the chemical attributes ( $\mathrm{Al}, \mathrm{OM}, \mathrm{S}, \mathrm{Ca}, \mathrm{Cu}, \mathrm{m} \%)$ on formation of the groups (Figure 3). The eigenvalues of 0.431 for the $1^{\text {st }}$ axis and of 0.285 for the $2^{\text {nd }}$ axis were indicated in analyzing the distribution of plots and species in relation to environmental factors for the arboreal vegetation belonging to Class I 
Table 3. Phytosociological parameters of the species belonging to Group 2, considering Class I and Class II in a Mixed Ombrophilous Forest fragment. São Francisco de Paula, RS, Brazil.

\begin{tabular}{|c|c|c|c|c|c|c|c|c|}
\hline \multirow{2}{*}{ SCIENTIFIC NAME } & \multicolumn{4}{|c|}{ CLASS I } & \multicolumn{4}{|c|}{ CLASS II } \\
\hline & AD & ADo & AF & VI & AD & ADo & AF & VI \\
\hline Araucaria angustifolia & 128.6 & 13.3374 & 85.7 & 20.6 & & & & \\
\hline Gymnanthes klotzschiana & 292.9 & 6.0145 & 71.4 & 19.6 & 257.1 & 1.1212 & 28.6 & 27.8 \\
\hline Lithraea brasiliensis & 107.1 & 6.0347 & 100.0 & 14.1 & 28.6 & 0.1278 & 28.6 & 5.9 \\
\hline Podocarpus lambertii & 85.7 & 3.4423 & 71.4 & 9.6 & 28.6 & 0.1484 & 28.6 & 6.1 \\
\hline Ilex brevicuspis & 28.6 & 2.0645 & 42.9 & 4.9 & 14.3 & 0.0604 & 14.3 & 2.9 \\
\hline Myrcianthes gigantea & 42.9 & 0.6563 & 57.1 & 4.9 & 14.3 & 0.0891 & 14.3 & 3.2 \\
\hline Eugenia uruguayensis & 50.0 & 0.8867 & 42.9 & 4.7 & 57.1 & 0.2859 & 28.6 & 9.0 \\
\hline Myrceugenia cucullata & 35.7 & 0.8953 & 42.9 & 4.2 & 100.0 & 0.7281 & 57.1 & 18.9 \\
\hline Ocotea pulchella & 28.6 & 0.5401 & 42.9 & 3.6 & 14.3 & 0.0555 & 14.3 & 2.9 \\
\hline Myrsine coriacea & 14.3 & 0.8684 & 28.6 & 2.7 & & & & \\
\hline Myrciaria delicatula & 28.6 & 0.4493 & 14.3 & 2.1 & 14.3 & 0.0360 & 14.3 & 2.7 \\
\hline Quillaja brasiliensis & 7.1 & 1.2467 & 14.3 & 2.0 & 14.3 & 0.2718 & 14.3 & 5.1 \\
\hline Prunus myrtifolia & 14.3 & 0.2909 & 14.3 & 1.5 & & & & \\
\hline Cinnamomum amoenum & 7.1 & 0.3869 & 14.3 & 1.3 & & & & \\
\hline Ilex dumosa & 7.1 & 0.3396 & 14.3 & 1.2 & & & & \\
\hline Allophylus edulis & 7.1 & 0.1365 & 14.3 & 1.1 & & & & \\
\hline Blepharocalyx salicifolius & 7.1 & 0.0909 & 14.3 & 1.0 & & & & \\
\hline Maytenus aquifolia & 7.1 & 0.0529 & 14.3 & 1.0 & & & & \\
\hline Acca sellowiana & & & & & 42.9 & 0.1628 & 14.3 & 5.4 \\
\hline Casearia decandra & & & & & 14.3 & 0.0860 & 14.3 & 3.2 \\
\hline Miconia cinerascens & & & & & 28.6 & 0.0636 & 14.3 & 3.7 \\
\hline Schinus lentiscifolia & & & & & 14.3 & 0.0745 & 14.3 & 3.1 \\
\hline TOTAL & 900.0 & 37.7339 & 700.0 & 100.0 & 642.9 & 3.3111 & 300.0 & 100.0 \\
\hline
\end{tabular}

AD: absolute density (individuals.ha $\left.{ }^{-1}\right)$; ADo: absolute dominance $\left(\mathrm{m}^{2} \cdot \mathrm{ha}^{-1}\right)$; AF: absolute frequency (\%); VI: value of importance (\%); Class I $(\mathrm{DBH} \geq 30 \mathrm{~cm})$; Class II $(15 \leq \mathrm{DBH}<30 \mathrm{~cm})$.

$(\mathrm{DBH} \geq 30 \mathrm{~cm})$. Monte Carlo permutation test was significant, presenting an error probability of 0.004 , thus indicating precision in the calculation of the correlations between the analyzed matrices.

All the analyzed chemical attributes showed higher correlation with the first ordering axis. Figure 3 shows the "biplot" ordination diagram obtained as a result of the CCA with the distribution of environmental variables in relation to the phytosociological groups.

Despite presenting high sulfur (S) levels for both groups (10.1 mg. dm ${ }^{-3}$ for the riparian forest with flat topography (G1) and $12.1 \mathrm{mg} \cdot \mathrm{dm}^{-3}$ for the hillside riparian forest (G2)) (Table 4), its higher values in G2 represent an explanatory variable for classifying this group. Regarding organic matter, this variable reached an average of $8.7 \%$ in G2, higher than that of G1 (5.8\%) (Table 4). These are interpreted as high values (SBCS, 2004), being the consequence of a greater humidity in the soil, presence of basaltic material, altitude and cold climate, resulting in slow decomposition of organic matter, and consequently acidic pH (5.4) (Table 4).

The diagram of Figure 3 shows that the soil chemical variables that most correlated the riparian forest with flat topography (G1) were $\mathrm{Al}, \mathrm{m} \%$ and $\mathrm{Cu}$. In this group, the concentration of exchangeable aluminum in the soil $\left(\mathrm{Al}^{3+}\right)$ was $3.9 \mathrm{cmol}_{\mathrm{c}} \cdot \mathrm{dm}^{-3}$; higher than the one found in $\mathrm{G} 2\left(1.3 \mathrm{cmol} \cdot \mathrm{dm}^{-3}\right)$, which can be attributed to the greater weathering of this environment and higher soil $\mathrm{pH}$ values. 
The variables $\mathrm{S}, \mathrm{Ca}$ and $\mathrm{MO}$ showed correlation with the hillside riparian forest (G2). Ca had the highest correlation of these, with mean values of 9.5 $\mathrm{cmol}_{c} \cdot \mathrm{dm}^{-3}$ for this group (Table 4 ), which is considered a high value according to Sociedade Brasileira de Ciência do Solo (SBCS, 2004).

The correlation of saturation by aluminum $(\mathrm{m} \%)$ and of copper with the riparian forest with flat topography (G1) may be related to higher concentrations of OM, since $\mathrm{Cu}$ is retained in the organic matter, forming stable complexes that play an important role in the mobility and availability of this micronutrient to plants (Abreu et al., 2007).

Therefore, it can be observed that specific environmental conditions in the studied riparian forest fragment have an influence in forming ecological niches, which despite being represented by similar species, occur in a differentiated manner in terms of density, dominance and frequency. A clear example was the Araucaria angustifolia, which stood out in the environment with less influence of the water table.

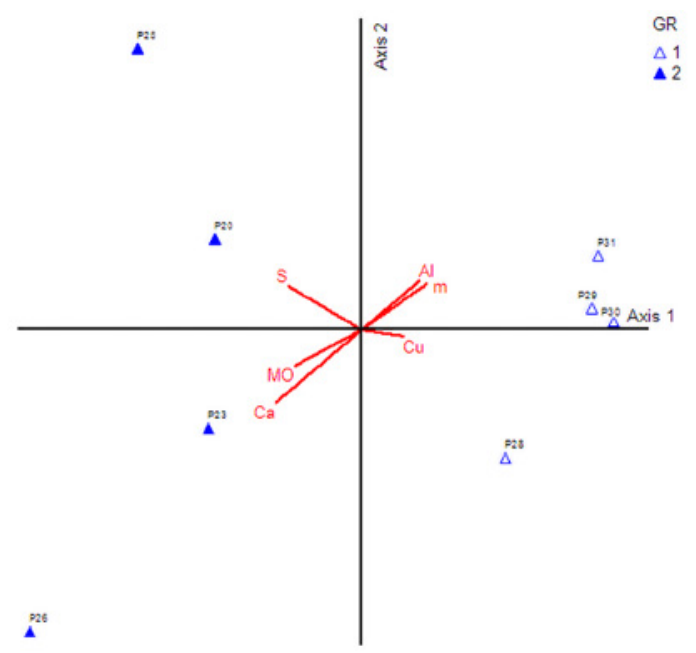

Figure 3. Ordination diagram produced by Canonical Correspondence Analysis for the first two axes for groups analyzed with the environmental variables in a Mixed Ombrophilous Forest fragment. São Francisco de Paula, RS, Brazil. GR: Group; Axis: axes; P: Plots; Al: Aluminum; m: Aluminum saturation; $\mathrm{Cu}$ : Copper; $\mathrm{Ca}$ : Calcium; OM: organic matter; S: Sulfur.

Table 4. Soil chemical attributes for phytosociological groups in Mixed Ombrophilous Forest Fragment. São Francisco de Paula, RS, Brazil.

\begin{tabular}{|c|c|c|}
\hline \multirow[b]{2}{*}{ Attributes } & \multicolumn{2}{|c|}{ Groups } \\
\hline & $\begin{array}{l}\text { Riparian forest with flat } \\
\text { topography }\end{array}$ & Hillside Riparian forest \\
\hline Active acidity (water $\mathrm{pH}$ ) & 4.8 & 5.4 \\
\hline Potential acidity $(\mathrm{H}+\mathrm{Al})\left(\mathrm{cmol}_{c} \cdot \mathrm{dm}^{-3}\right)$ & 17.5 & 9.6 \\
\hline Aluminum $\left(\mathrm{cmol}_{\mathrm{c}} \cdot \mathrm{dm}^{-3}\right)$ & 3.9 & 1.3 \\
\hline Calcium $\left(\mathrm{cmol}_{c} \cdot \mathrm{dm}^{-3}\right)$ & 2.9 & 9.5 \\
\hline Magnesium $\left(\mathrm{cmol}_{\mathrm{c}} \cdot \mathrm{dm}^{-3}\right)$ & 1.3 & 2.5 \\
\hline Potassium (mg.dm ${ }^{-3}$ ) & 77.0 & 90.0 \\
\hline Phosphorus (mg.dm ${ }^{-3}$ ) & 3.0 & 3.5 \\
\hline Sulfur (mg.dm $\left.{ }^{-3}\right)$ & 10.1 & 12.1 \\
\hline Copper (mg.dm³ ${ }^{-3}$ & 3.5 & 2.5 \\
\hline Zinc $\left(\mathrm{mg} \cdot \mathrm{dm}^{-3}\right)$ & 2.6 & 4.7 \\
\hline Boron $\left(\mathrm{mg} \cdot \mathrm{dm}^{-3}\right)$ & 0.5 & 0.5 \\
\hline Organic matter (\%) & 5.8 & 8.7 \\
\hline Saturation by aluminum (m\%) & 49.5 & 13.9 \\
\hline Base saturation (V\%) & 26.3 & 56.6 \\
\hline Effect CEC $\left(\mathrm{cmol}_{c^{\prime}} \cdot \mathrm{dm}^{-3}\right)$ & 8.2 & 13.6 \\
\hline pH7 CEC $\left(\mathrm{cmol}^{\left.-\mathrm{dm}^{-3}\right)}\right.$ & 21.8 & 21.9 \\
\hline
\end{tabular}

Phosphorus extracted by Mehlich method; Effect CEC: Effective cation exchange capacity; pH7 CEC: Potential cation exchange capacity. 


\section{CONCLUSIONS}

In the studied riparian forest fragment, there are two clusters of arboreal components, which despite having similarity in the floristic composition, presented differences in the vegetation structure due to topographic and consequently edaphic aspects.

Soil chemical attributes are indicators of ecological niches that even when represented by similar species, occur in different manners in terms of density, dominance and frequency.

\section{SUBMISSION STATUS}

Received: 2 Apr., 2014

Accepted Date: 16 Nov. 2017

\section{CORRESPONDENCE TO}

\section{Mônica Brucker Kelling}

Universidade Federal de Santa Maria (UFSM), Av. Roraima, 1000, CEP 97105-900, Cidade Universitária, Camobi, Santa Maria, RS, Brazil e-mail:mbk@politecnico.ufsm.br

\section{REFERENCES}

Abreu CA, Lopes AS, Santos G. Micronutrientes. In: Novais RF, Alvarez VH, Barros NF, Fontes RLF, Cantarutti RB, Lima JC, editors. Fertilidade do solo. Viçosa: Sociedade Brasileira de Ciência do Solo; 2007. p. 645-736.

Araujo MM, Chami L, Longhi SJ, Ávila AL, Brena DA. Análise de agrupamento em remanescente de Floresta Ombrófila Mista. Ciência Florestal 2010; 20(1): 1-18. 10.5902/198050981755

Avila AL, Araujo MM, Longhi SJ, Gasparin E. Agrupamentos florísticos na regeneração natural em remanescente de Floresta Ombrófila Mista, RS, Brasil. Scientia Forestalis 2011; 39(91): 331-342.

Backes P, Irgang B. Árvores do Sul: guia de identificação e interesse ecológico. 2nd ed. Porto Alegre: Paisagem do Sul; 2009.

Brancalion PHS, Rodrigues RR, Gandolfi S, Kageyama PY, Nave AG, Gandara FB et al. Legal instruments can enhance high-diversity tropical forest restoration. Revista Árvore 2010; 34(3): 455-70. 10.1590/S0100-67622010000300010

Brasil. Lei no 12.651, de 25 de maio de 2012. Dispõe sobre a proteção da vegetação nativa e dá outras providências. Diário Oficial da República Federativa do Brasil, Brasília,
DF, (2012 maio 25) [cited 2017 jun. 20]. Available from: https://bit.ly/1zecCID

Chase MW. An update of the Angiosperm Phylogeny Group classification for the orders and families of flowering plants: APG IV. Botanical Journal of the Linnean Society 2016; 181(1): 1-20. 10.1111/boj.12385

Felfili JM, Rezende RP. Conceitos e métodos em fitossociologia. Brasília, DF: UnB; 2003.

Gauch HG Jr. Multivariate analysis in community ecology. Cambridge: Cambridge University Press; 1982.

Instituto Brasileiro de Geografia e Estatística - IBGE, cartographer. Mapa de biomas do Brasil [map]. Rio de Janeiro: IBGE; 2004 [cited 2019 maio 7]. Available from: https://bit.ly/2BAXYRs

Instituto Brasileiro de Geografia e Estatística - IBGE. Manual técnico da vegetação brasileira: sistema fitogeográfico, inventário das formações florestais e campestres, técnicas e manejo de coleções botânicas, procedimentos para mapeamentos. 2nd ed. Rio de Janeiro: IBGE; 2012.

Jardim Botânico do Rio de Janeiro - JBRJ. Lista de espécies da flora do Brasil. Rio de Janeiro: Reflora; 2014.

Kageyama PY, Gandara FB. Recuperação de áreas ciliares. In: Rodrigues, RR, Leitão Filho, HF, editors. Matas ciliares: conservação e recuperação. 2nd ed. São Paulo: Edusp; 2009.

McCune B, Mefford MJ. PC-ORD for Windows: multivariate analysis of ecological data - version 3.12. Oregon: MJM Software Design, Gleneden Beach; 1997.

Moreno JA. Clima do Rio Grande do Sul. Boletim Geográfico do Rio Grande do Sul 1961; 11: 49-73.

Péllico Neto S, Brena DA. Inventário florestal. Curitiba: Authors; 1997.

Pillar VP, Müller SC, Castilhos, ZMS, Jacques AVA, editors. Campos sulinos: conservação e uso sustentável da biodiversidade. Brasília, DF: Ministério do Meio Ambiente; 2009.

Ribeiro SB, Longhi SJ, Brena DA, Nascimento ART. Diversidade e classificação da comunidade arbórea da Floresta Ombrófila Mista da Flona de São Francisco de Paula, RS. Ciência Florestal 2007; 17(2): 101-8. $10.5902 / 198050981941$

Rodrigues LA, Carvalho DA, Oliveira Filho AT, Curi N. Efeitos de solos e topografia sobre a distribuição de espécies arbóreas em um fragmento de floresta estacional semidecidual, em Luminárias, MG. Revista Árvore 2007; 31(1): 25-35.

Rodrigues RR. Florestas ciliares? Uma discussão nomenclatural das formações ciliares. In: Rodrigues RR, Leitão Filho HF, editors. Matas ciliares: conservação e recuperação. 2nd ed. São Paulo: Edusp; 2009. p. 91-99.

Rorato DG, Araujo MM, Tabaldi LA, Tonetto TS, Rovedder APM, Dutra AF. Influência dos fatores ambientais no componente arbóreo de fragmentos florestais em São 
Francisco de Paula - Rio Grande do Sul. Cerne 2015; 21(4): 561-8.

Sociedade Brasileira de Ciência do Solo - SBCS. Manual de adubação e calagem para os Estados do Rio Grande do Sul e Santa Catarina. 10th ed. Porto Alegre: Comissão de Química e Fertilidade do Solo; 2004.
Streck EV, Kämpf N, Dalmolin RSD, Klamt E, Nascimento PC, Schneider P et al. Solos do Rio Grande do Sul. 2nd ed. Porto Alegre: Emater; 2008.

Tedesco MJ, Gianello C, Bissani CA, Bohnen H, Volkweiss SJ. Análises de solos, plantas e outros materiais. 2nd ed. Porto Alegre: UFRGS; 1995. 